\title{
Związek między reformą założeń, procesu i rezultatów nauczania języka czeskiego ${ }^{1}$
}

\author{
The relations between the reform of input, process, \\ and results of Czech language teaching
}

\begin{abstract}
The paper deals with the key problem of creating the learning and teaching environment: the relation of the input, processes and output of instruction. In Czech language teaching, we observe that their separation results in problems, especially in the area of the processes and results of instruction. On the one hand, we see innovative educational policies and field didactic theories; on the other hand, we have educational practices that remain in traditional, rather rigid positions. All that collides with the requirements of standardized examinations, which have greater influence on educational practice than educational policies or curricula. All in all, for all innovations in education, cohesion between the input, processes and output is an absolute necessity.
\end{abstract}

Keywords: innovations, educational policies, L1 didactics, Czech language, curriculum, teaching processes, standardized examinations.

${ }^{1}$ Pojęcia założeń, procesu i rezultatów nauczania języka czeskiego, użyte w opracowaniu, nawiązują do terminologii naukowej dydaktyki języka czeskiego. Zostały zastosowane w moim wykładzie habilitacyjnym zatytułowanym Vztah vstupové, procesové a výstupové reformy ve výuce českého jazyka, wygłoszonym na Wydziale Pedagogicznym Uniwersytetu Karola w Pradze w dniu 18 czerwca 2020 roku. Wykład ten stanowi podstawę niniejszego opracowania. Serdecznie dziękuję Pani prof. dr hab. Bernadecie Niesporek-Szamburskiej za szlachetną pomoc w przygotowaniu polskojęzycznej wersji tego artykułu. 


\section{Wprowadzenie - podstawowe pytania}

Artykuł Tomáša Janíka Škola na kruhovém objezdu aneb když se to vezme kolem a kolem ${ }^{2}$ [Szkoła na rondzie lub krażenie naokoło i dookola] zainspirował mnie do zastanowienia się nad związkiem między założeniami, procesem kształcenia i rezultatami w nauczaniu języka czeskiego. Trudną, skomplikowaną, a być może przełomową sytuację dobrze określa frazeologizm sięgający metaforycznie do sytuacji drogowej — „być na rozdrożu”. Tego właśnie sformułowania użył Janík w swoich rozważaniach, aby przedstawić „,szkołę zmierzającą w kierunku rozdroża reform mającego charakter ronda"3. Autor celowo wybiera metaforę ronda, które zwiększa bezpieczeństwo ruchu, a jednocześnie umożliwia jeżdżenie w koło, gdy nie ma pewności, którą drogę wybrać. Uznaję, podobnie jak Janík, że istnieje potrzeba stworzenia w odniesieniu do nauczania języka czeskiego czegoś w rodzaju „mapy krajobrazu edukacyjnego" — chodzi o to, by określić, które „ścieżki” prowadzą do „ronda” edukacji szkolnej, a którymi można rondo opuścić.

We wspomnianym artykule Janík odnosi swe rozważania do ustaleń pedagogiki ogólnej, z kolei ja chciałbym się skupić na poziomie dydaktyki przedmiotowej języka czeskiego na tle szerszego kontekstu pedagogicznego. Podobnie jak Janík rozważam trzy główne kwestie:

— założenia nauczania;

— proces nauczania;

- rezultaty reformowania procesu nauczania ${ }^{5}$.

Kwestia reform i innowacji ma bowiem dla edukacji kluczowe znaczenie. Dlatego pytania podstawowe w moich rozważaniach są następujące:

1. W jaki sposób myślę o innowacjach w nauczaniu języka czeskiego?

2. Czy w nauczaniu języka czeskiego stworzono systemowe warunki dla wprowadzanych innowacji?

${ }^{2}$ T. Janík: Škola na kruhovém objezdu aneb když se to vezme kolem a kolem. „Pedagogická orientace" 2015, č. 5, s. 727-732; w wersji rozszerzonej: Idem: Škola na kruhovém objezdu aneb Když se to vezme kolem a kolem. W: Vzděláni a dnešek. Red. M. Strouhal, S. Štech. Karolinum, Praha 2016, s. 163-178.

3 T. Janík: Škola na kruhovém objezdu... (2015), s. 727. Wszystkie cytaty w przekładzie autora artykułu.

${ }^{4}$ Ibidem, s. 728.

${ }^{5}$ W zakończeniu artykułu skomentuję czwartą kwestię, którą Janík nazywa „EDUout”. 


\section{Metafora „ronda” w nauczaniu języka czeskiego}

Z wielu źródeł wynika, że współcześnie nauczanie języka ojczystego — nie tylko w Republice Czeskiej i w Polsce, lecz także szerzej, w skali międzynarodowej - odbywa się w nowym kontekście. Poszczególne symptomy tego kontekstu to między innymi ${ }^{6}$ :

1. Globalizacja, to jest integracja gospodarcza, społeczna i kulturowa.

2. Plurikulturalizm, który jest związany z migracją populacji i oznacza spotykanie i przenikanie się różnych kultur?

3. Zmiany technologiczne i kulturowe, które zasadniczo wpływają na komunikację ${ }^{8}$. We współczesnej komunikacji obraz odgrywa kluczową rolę (mówimy o pokoleniu ekranów), komunikacja zmienia się z werbalnej na wizualną - potrzebne są więc nowe kompetencje, między innymi kompetencje wizualne. Dlatego na przykład w australijskiej podstawie programowej do czterech umiejętności komunikacyjnych: czytanie, pisanie, mówienie i słuchanie, dodano dwie kolejne: oglądanie (viewing) i tworzenie (creating) ${ }^{9}$. Następuje zwrot w kierunku mowy i jej ekspansja we wszystkich sferach komunikacji ${ }^{10}$, a także zmiana statusu komunikacji pisemnej i ustnej oraz związane z tym przeplatanie się różnych warstw językowych w tekstach pełniących rozmaite funkcje. Nauczanie języka ojczystego - w porównaniu $\mathrm{z}$ nauczaniem innych przedmiotów szkolnych - jest $\mathrm{z}$ tego powodu w sytuacji specyficznej: zmienia się nie tylko narzędzie, lecz także sama materia nauczania.

4. Rozwój językoznawstwa, względnie nauki o języku, a mianowicie przełom komunikacyjny i pragmatyczny, który nastąpił w latach sześćdziesiątych i siedemdziesiątych ubiegłego wieku i przyniósł nowe paradygmaty i perspektywy językowe, umożliwiające pojawienie się nowych dyscyplin

${ }^{6}$ Ostatnio w szerokiej perspektywie międzynarodowej por. Rethinking L1 education in the global era. Understanding the (post-)national L1 subjects in new and difficult times. Eds. B. Green, P.O. Erixon. Springer, New York 2020.

7 Świadomie nie stosuję terminu ,wielokulturowość”, który często jest obarczony różnymi pobocznymi znaczeniami; terminu ,plurikulturalizm” używam celowo i rozumiem go jako neutralny.

${ }^{8}$ Obszerne omówienie w: J. Nocoń: Lingwodydaktyka na progu XXI wieku. Konteksty koncepcje - dylematy. Wydawnictwo Uniwersytetu Opolskiego, Opole 2018; także: S. Štěpáník: Výuka češtiny mezi tradicí a inovací. Academia, Praha 2020.

9 ACARA: The Australian curriculum: English version 8.3. Australian Government, Sydney 2016.

${ }^{10}$ Por. J. Hoffmannová et al.: Stylistika mluvené a psané češtiny. Academia, Praha 2016; Style wspótczesnej polszczyzny. Przewodnik po stylistyce polskiej. Red. E. Malinowska, J. Nocoń, U. Żydek-Bednarczuk. Towarzystwo Autorów i Wydawców Prac Naukowych Universitas, Kraków 2013. 
językowych, takich jak lingwistyka kognitywna, lingwistyka korpusowa, pragmatyka itp.

5. Rozwój nauk pedagogicznych upowszechniających — dążenie do nowej kultury nauczania i uczenia się, której głównym nurtem myślowym jest konstruktywizm dydaktyczny ${ }^{11}$.

\section{Założenia w nauczaniu języka czeskiego}

Zasadnicze postulaty nauczania na poziomie założeń są formułowane w ramach polityki edukacyjnej państwa. Podstawowymi dokumentami oświatowymi w Republice Czeskiej są Strategia polityki edukacyjnej Republiki Czeskiej 2030+ (Strategie vzdélávací politiky ČR 2030+; w skrócie: Strategia 2030+) oraz podstawy programowe dla poszczególnych etapów edukacji (system poszczególnych Ramowych programów edukacyjnych; w skrócie RPE - Rámcový vzdělávací program).

Strategia 2030+ (a także obowiązująca przed nią Strategia polityki edukacyjnej 2020) wyznacza podstawowe cele i kierunki edukacji w Republice Czeskiej. Dokument był poddany stosunkowo intensywnej i wieloetapowej publicznej dyskusji, obudowano go licznymi komentarzami. Strategia 2030+ została zatwierdzona w listopadzie 2020 roku (w tym artykule opieram się na wersji roboczej z 31 października 2019 roku). Główne cele Strategii 2030+ to:

— „skoncentrowanie edukacji bardziej na nabywaniu kompetencji potrzebnych do aktywnego życia społecznego, zawodowego i osobistego" (SC1);

— „zmniejszanie nierówności edukacyjnych i zwiększanie równego dostępu do edukacji” (SC2).

Dwie z czterech strategicznych linii polityki edukacyjnej państwa to „zmiana treści i metod edukacji” (SL1) oraz „wspieranie nauczycieli, dyrektorów i innych pracowników oświaty" (SL2) ${ }^{12}$. Koncepcja państwa jest zatem nastawiona na reformowanie i ma na celu wdrażanie innowacji. Warto to wziąć pod uwagę w rewizji Ramowych programów edukacyjnych, podstawowego dokumentu programowego Republiki Czeskiej, który będzie kontynuacją Strategii 2030+ i w istocie stanie się jednym z jej kluczowych narzędzi w praktyce edukacyjnej.

W zakresie nauczania języka i literatury czeskiej już obecna podstawa programowa umożliwia nauczycielom podejście komunikacyjne oraz dostosowanie do niego treści nauczania i sposobów ich prezentacji dydaktycznej. Poli-

${ }^{11}$ T. Janík: Od reformy kurikula k produktivní kultuře vyučování a učení. „Pedagogická orientace" 2013, č. 5, s. $634-663$.

${ }_{12}$ Wszystko cytowane na stronie: Ministerstvo školství, mládeže a tělovýchovy. https://www. msmt.cz/vzdelavani/skolstvi-v-cr/strategie-2030 [dostęp: 5.06.2019]. 
tyka edukacyjna i podstawa programowa są więc teoretycznie zgodne $\mathrm{z}$ tezami współczesnej dydaktyki przedmiotowej języka czeskiego ${ }^{13}$. W weryfikacji podstawy programowej dla szkół podstawowych i średnich powinno się dodatkowo położyć nacisk na:

— integralne podejście do elementów przedmiotu (język, styl — komunikacja i edukacja literacka);

- ukierunkowanie nauczania na cele kognitywno-komunikacyjne ${ }^{14}$; oraz

— zastosowanie w nauczaniu zasad konstruktywistycznych ${ }^{15}$.

Jako członek grupy ekspertów, która działała w Narodowym Instytucie Edukacji (Národní ústav pro vzdělávání) i zajmowała się weryfikacją RPE (podstawy programowej) do połowy 2019 roku, kiedy to Ministerstwo Edukacji zawiesiło prace, mogę potwierdzić, że modyfikacja RPE skoncentrowana była bezsprzecznie na osiągnięciu wskazanych celów.

Podstawowymi zagadnieniami istotnymi w budowaniu warunków dla nauczania i uczenia się języka czeskiego - kwestiami, które rozwiązuje współczesna dydaktyka przedmiotowa, a które muszą zostać rozstrzygnięte również w nowej podstawie programowej - są:

- respektowanie związku między transformacją ontodydaktyczną i psychodydaktyczną, który wpływa na samą treść, ewentualnie na dobór treści i sposób jej przetwarzania dydaktycznego;

- osiąganie integralności w nauczaniu (integrita výuky) ${ }^{16}$, to jest zgodności wiedzy na temat dyscypliny przedmiotowej oraz podstaw teorii kształcenia i uczenia się języka ojczystego z perspektywą ucznia;

${ }_{13}$ Por. m.in. M. Čechová: Teorie a praxe vyučování českému jazyku na gymnáziu. Univerzita Karlova, Praha 1982; Eadem: Vyučováni slohu. (Úvod do teorie). Státní pedagogické nakladatelství, Praha 1985; Eadem: Komunikační a slohová výchova. ISV, Praha 1998; M. Čechová, V. Styblík: Čeština a její vyučování. Didaktika českého jazyka pro učitele základních a středních škol a studenty učitelství. 2., upravené vyd., v SPN vyd. 1. SPN, Praha 1998; E. Hájková: Komunikační činnosti a jejich cíle. Pedagogická fakulta Univerzity Karlovy, Praha 2008; J. Svobodová: Jazyková specifika školské komunikace a výuka mateřštiny. Ostravská univerzita. Pedagogická fakulta, Ostrava 2003; K. Šebesta: Od jazyka ke komunikaci. Didaktika českého jazyka a komunikační výchova. Vyd. 2. Karolinum, Praha 2005; S. Štěpáník: Kognitivně-komunikační princip jako základni východisko výuky českého jazyka. „Český jazyk a literatura” 2018/2019, č. 5, s. 214-223; Idem: Výuka češtiny mezi tradicí a inovací...; Idem: Konstruktivistické a kognitivně-komunikační paradigma jako východisko koncepce výuky českého jazyka. „Pedagogika” 2020, č. 1, s. 5-28. https://doi.org/10.14712/23362189.2019.1355.

${ }^{14}$ Dla obu por. L'. Liptáková et al.: Integrovaná didaktika slovenského jazyka a literatúry pre primárne vzdelávanie. Prešovská univerzita v Prešove, Pedagogická fakulta, Katedra komunikačnej a literárnej výchovy, Prešov 2011.

${ }_{15}$ Dla wszystkich trzech wymienionych akcentów por. S. Štěpáník et al.: Vztah jazyka a komunikace v česko-slovensko-polské didaktické reflexi. Karolinum, Praha 2019.

${ }^{16}$ J. Slavík et al.: Transdisciplinární didaktika: o učitelském sdíleni znalostí a zvyšování kvality výuky napřič obory. Masarykova univerzita, Pedagogická fakulta, Brno 2017. https://doi. org/10.5817/CZ.MUNI.M210-8569-2017. 
- osiąganie harmonii pomiędzy elementami, które decydują o jakości nauczania, to jest organizacją oraz zarządzaniem klasą, doborem celów i treści nauczania, rodzajami zadań edukacyjnych, a także wspierającym klimatem uczenia się ${ }^{17}$.

Wszystkie wymienione komponenty stanowią istotę nauczania języka czeskiego w szkole i uzasadniają postawienie pytania, jakiego nauczania języka czeskiego potrzebujemy. Od dawna wskazywano, że obszarem krytycznym jest nauczanie języka, a ściślej - nauczanie gramatyki. Aby kształtować środowisko nauczania i uczenia się (nie tylko) języka czeskiego, należy zatem rozstrzygnąc kwestie związane z pozycją i ze znaczeniem gramatyki w nauczaniu języka ojczystego oraz powiązaniem nauczania gramatyki z rozwojem umiejętności komunikacyjnych uczniów. Obydwa wymienione obszary stanowią przedmiot dydaktyki wielu języków ojczystych, nie tylko w czeskim środowisku językowym ${ }^{18}$, lecz także poza nim ${ }^{19}$. Przy rozwiązywaniu wskazanych kwestii proponuje się więc perspektywę porównawczą, czyli poszukiwanie punktów wspólnych w dydaktykach różnych języków - w naszym środo-

${ }_{17}$ T. Janík, V. Lokajíčková, T. Janko: Komponenty a charakteristiky zakládající kvalitu výuky: přehled výzkumných zjištění. „Orbis scholae” 2012, č. 3, s. 27-55. https://doi. org/10.14712/23363177.2015.31.

${ }_{18}$ Por. na przykład K. Bakuła: Kształcenie językowe w szkole podstawowej w świetle wspótczesnych teorii psycholingwistycznych i lingwistycznych. Projekt nowej metodyki. Wydawnictwo Uniwersytetu Wrocławskiego, Wrocław 1997; V. Betáková, Ž. Tarcalová: Didaktika materinského jazyka. Slovenské pedagogické nakladatel'stvo, Bratislava 1981; V. Betáková, J. Jacko, K. Zelinková: Teória vyučovania slovenského jazyka. Slovenské pedagogické nakladatel'stvo, Bratislava 1984; A. Dyduchowa: Metody ksztatcenia sprawności językowej uczniów: projekt systemu, model podręcznika. Wydawnictwo Naukowe WSP, Kraków 1988; J. Kowalikowa, H. Synowiec: Miejsce nauki o języku w kształceniu językowym uczniów. W: Kształcenie sprawności językowej i komunikacyjnej. Obraz badań i działań dydaktycznych. Red. Z. Uryga, M. Sienko. Wydawnictwo Naukowe Akademii Pedagogicznej, Kraków 2005, s. 48-56; L. Liptáková et al.: Integrovaná didaktika slovenského jazyka a literatúry pre primárne vzdelávanie...; M. Nagajowa: Nauka o języku dla nauki języka. Poradnik metodyczny dla nauczycieli języka polskiego. Wydawnictwo Pedagogiczne ZNP, Kielce 1994; J. Nocoń: Lingwodydaktyka na progu XXI wieku...; J. Palenčárová, J. Kesselová, J. Kupcová: Učime slovenčinu komunikačne a záżitkovo. Slovenské pedagogické nakladatel'stvo - Mladé letá, Bratislava 2003; M. Szymańska: Między nauka o języku a rozwijaniem języka. Koncepcje kształcenia językowego na przełomie XX i XXI wieku. Wydawnictwo Naukowe UP, Kraków 2016; kompleksowo: S. Štěpáník et al.: Vztah jazyka a komunikace...; Teaching of national languages in the V4 countries. Eds. M. Pieniążek, S. Štěpáník. Charles University in Prague, Praha 2016.

${ }_{19}$ Na przykład: Beyond the grammar wars: A resource for teachers and students on developing language knowledge in the English/literacy classroom. Ed. T. Locke. Routledge, New York 2010; Language in the schools: Integrating linguistic knowledge into K-12 teaching. Eds. K. Denham, A. Lobeck. Routledge, New York 2009; Knowing about language: Linguistics and the secondary English classroom. Eds. M. Giovanelli, D. Clayton. Routledge, London 2016; Grammar at school: Research on metalinguistic activity in language education. Eds. T. Ribas, X. Fontich, O. Guasch. Peter Lang AG, Brussels 2014. 
wisku językowym szczególnie istotne będą podobieństwa czesko-polsko-słowackie ${ }^{20}$.

\section{Proces nauczania języka czeskiego}

Tradycja nauczania języka czeskiego ma niemal 200 lat, a jej korzenie sięgają między innymi do okresu działalności tradycyjnych gramatyków (na przykład Raimunda J. Wursta lub Karla F. Beckera), którzy uznawali nauczanie gramatyki za doskonałą szkołę myślenia ${ }^{21}$. Chociaż dydaktyka promuje koncepcję komunikacyjną w nauczaniu języka od przełomu lat siedemdziesiątych i osiemdziesiątych XX wieku ${ }^{22}$, nadal silna jest tradycja gramatyczna ${ }^{23}$. Podobnie sytuacja wygląda w Polsce ${ }^{24}$.

Główne słabości w nauczaniu języka czeskiego, które w dużej mierze wynikają z tej koncepcji, można podać w następującym wyliczeniu:

1. Atomizacja treści, mechaniczne nabywanie i formalne zastosowanie wiedzy, bez rzeczywistego zrozumienia ${ }^{25}$.

${ }^{20}$ Por. S. Štěpáník et al.: Vztah jazyka a komunikace...; Teaching of national languages in the V4 countries...; Język ojczysty w edukacji szkolnej w Polsce, Czechach i na Stowacji. Red. E. Awramiuk, S. Štěpáník. Wydawnictwo Uniwersytetu, Białystok 2020.

${ }^{21}$ Por. J. Jelínek: Nástin dějin vyučování českému jazyku v letech 1774-1918. Státni pedagogické nakladatelství, Praha 1972.

${ }^{22}$ Por. M. Šmejkalová: Čeština a škola - úryvky skrytých dějin. Karolinum, Praha 2010; S. Štěpáník, L. Liptáková, M. Szymańska: Cesty ke komunikačně-funkčnímu pojetí v české, slovenské a polské didaktice mateřského jazyka. W: S. Štěpáník et al.: Vztah jazyka a komunikace..., s. $23-71$.

${ }^{23}$ S. Štěpáník: Výuka češtiny mezi tradicí a inovací...

${ }^{24}$ Por. J. Nocoń: Lingwodydaktyka na progu XXI wieku...; M. Szymańska: Kształcenie językowe w dyskursie edukacyjnym po 1990. W: Świadomość językowa. Red. J. Nocoń, A. Tabisz. [Język a Edukacja. 3]. Wydawnictwo Uniwersytetu Opolskiego, Opole 2014, s. 143-159.

${ }_{25}$ Por. na przykład: R. Adam: Určování morfologických kategorií jmen: sonda do praktik začinajících studentů bohemistiky. „Didaktické studie” 2018, č. 1, s. 13-30; Idem: Určování morfologických kategorii sloves: sonda do praktik začinajicich studentů bohemistiky. „Didaktické studie” 2019, č. 1, s. 56-80; R. Adam et al.: Co neuměji studenti bohemistiky. „Český jazyk a literatura" 2010/2011, č. 1, s. 8-14; M. Čechová: Srovnání nesrovnatelného: Znalosti funkční morfologie u žáků před 50 lety a dnešnich bohemistů. „Český jazyk a literatura” 2018/2019, roč. 69, č. 1, s. 24-33; M. Chvál, M. Šmejkalová: Řešeni úloh z české syntaxe žáky 4.-9. ročniků základnich škol. „Studia paedagogica” 2018, roč. 23, č. 1, s. 106-134. https://doi.org/10.5817/SP2018-1-6; J. Jelínek, M. Těšitelová, V. Styblík: Vyučování českému jazyku v osmém postupném ročníku. Státni pedagogické nakladatelství, Praha 1957; S. Štěpáník: Přiklad výzkumu žákovských představ v české syntaxi. „Pedagogická orientace” 2014, č. 1, s. 111-127. https://doi.org/10.5817/PedOr2014-1-111; Idem: Výuková situace: transformace větného členu na větu a naopak v kontextu 
2. Brak uzasadnienia dla wyboru treści ${ }^{26}$.

3. Terminologiczno-definicyjny charakter nabytej wiedzy ${ }^{27}$.

4. Nieadekwatność poznawcza treści ${ }^{28}$.

5. Nieodpowiednie metody nauczania (niektóre z nich stały się celem zamiast środkiem $)^{29}$.

6. Stopniowa utrata motywacji uczniów - aż do całkowitego jej braku ${ }^{30}$.

7. Brak podejścia semantyczno-pragmatycznego, dysfunkcyjne wykorzystanie znajomości treści językowych w praktyce komunikacyjnej ${ }^{31}$.

Zarysowane problemy można podsumować stwierdzeniem, że utrzymująca się w czeskiej szkole koncepcja nauczania czyni z uczniów „małych lingwistów”

větného rozboru. „Komenský” 2016, č. 4, s. 30-39; S. Štěpáník, J. Slavík: Žákovské prekoncepty jako konstitutivní prvek výuky mateřského jazyka. „Pedagogická orientace” 2017, č. 1, s. 58 -80. https://doi.org/10.5817/PedOr2017-1-58; L. Zimová: Ještě jednou k výuce skladbě. „Český jazyk a literatura" 2015/2016, č. 4, s. 164-169.

${ }^{26}$ Por. na przykład R. Adam: V karanténě s Novou školou aneb Řikej věty v množném čisle, slepče! „Český jazyk a literatura” 2019/2020, roč. 70, č. 5, s. 235-240; K. Rysová: Několik postřehů z výuky českého jazyka a literatury na Sک̌. „Český jazyk a literatura” 2005/2006, č. 5, s. 232-234; L. Zimová: Když se řekne skladba... „Český jazyk a literatura“ 2005/2006, č. 5, s. 209-214; Eadem: Ještě jednou k výuce skladbě...; S. Štěpáník: Výuková situace...; Idem: Výuka češtiny mezi tradicí a inovací...

${ }^{27}$ Por. na przykład R. Adam: V karanténě s Novou...; S. Štěpáník: Výuka češtiny mezi tradici a inovací...

${ }^{28}$ Por. na przykład R. Adam: V karanténě s Novou školou...; E. Hájková: Učivo o větě na 1. stupni ZŠ. „Didaktické studie” 2013, č. 2, s. 11-19; Eadem: Vztah komunikační a jazykové výchovy na př́kladu využití učiva mluvnice. W: S. Štěpáník et al.: Vztah jazyka a komunikace..., s. 173-190; S. Štěpáník: Výuka češtiny mezi tradicí a inovací...

${ }^{29}$ Por. na przykład M. Čechová: Zrušime nejen větné rozbory? „Český jazyk a literatura” 2011/2012, roč. 62, č. 5, s. 237-241; K. Hausenblas: Větný rozbor, nebo nalepování vinětek? „Český jazyk a literatura” 1965/1966, č. 3, s. 207-213; J. Hrbáček: Text a jeho rozbor ve škole. „Český jazyk a literatura” 1999/2000, č. 5-6, s. 109-116; S. Štěpáník: Výuková situace...; L. Zimová: O potřebnosti větného rozboru. „Český jazyk a literatura” 2011/2012, č. 5, s. $241-244$.

${ }^{30}$ Por. na przykład I. Pavelková: Postoje žáků k českému jazyku a jejich percepce učiteli. „Didaktické studie” 2013, č. 1, s. 27-45; I. Pavelková, A. Škaloudová, V. Hrabal: Analýza vyučovacích předmétů na základě výpovédí žáků. „Pedagogika” 2010, č. 1, s. 38-61.

${ }^{31}$ Por. na przykład M. Čechová: O potřebě integrace komunikačni a systémové jazykové výuky. „Český jazyk a literatura” 1993/1994, č. 7—8, s. 158—162; M. Kotenová: Je komunikačně orientovaná výuka skladby nedostižnou metou? „Český jazyk a literatura” 2018/2019, č. 2, s. 59-66; J. Hrbáček: K rozboru syntaktických vztahů ve škole. "Český jazyk a literatura” 1998/1999, č. 1-2, s. 14-25; Idem: Text a jeho rozbor ve škole. „Český jazyk a literatura” 1999/2000, č. 5-6, s. 109-116; S. Štěpáník: Výuka češtiny mezi tradici a inovací...; S. Štěpáník, M. Chvál: Konstruktivismus jako cesta ke zlepšováni výsledků vzdělávání v českém jazyce? „Studia paedagogica" 2016, č. 1, s. 35-56. https://doi.org/10.5817/SP2016-1-3; L. Zimová: Vyjadřování větných členů infinitivem jako problém didaktický. „Český jazyk a literatura” 1997/1998, č. 9-10, s. 205-211; Eadem: Způsoby vyjadřování podmětu jako problém didaktický. „Český jazyk a literatura" 1998/1999, č. 3-4, s. 63-67. 
(opanowujących „małą lingwistykę”), zamiast pomóc im zostać kompetentnymi użytkownikami języka ojczystego.

Największy problem w nauczaniu czeskiego stanowi dezintegracja elementów językowych i komunikacyjnych przedmiotu, tj. oddzielenie języka od komunikacji - tak jakby język nie był narzędziem komunikacji, a komunikacja nie odbywała się (między innymi) w języku. Zdezintegrowanie środowiska nauczania i uczenia się oznacza, że perspektywa kształcenia czy koncepcja nauczania i uczenia się są praktycznie odłączone od pojęć przedmiotowych oraz od perspektywy ucznia, a to głównie jego kompetencje powinny być rozwijane (w przypadku nauczania języka ojczystego powinno się nade wszystko łączyć wiedzę językową i umiejętności komunikacyjne $)^{32}$.

Jak można wnioskować z przytaczanych wcześniej źródeł, w których opisano przedstawione problemy, te zjawiska krytyczne spotykane są od dawna. Jesteśmy świadkami znacznej bezwładności tradycyjnej praktyki oraz przekazywania przez pokolenia nauczycieli swoistych „skamieniałości” (dogmatów czy stereotypów) w doborze treści i sposobie ich dydaktycznego przetwarzania. Już wcześniej komentowałem obszernie przyczyny takiego stanu rzeczy ${ }^{33}$ : za jedną z głównych można uznać fakt, że dotychczas w dydaktyce języka czeskiego brakowało specyficznej operacjonalizacji podstawowych tez dydaktyki kognitywno-komunikacyjnej i konstruktywistycznej - nie tworzono innowacyjnej kultury nauczania i uczenia się języka czeskiego w szkole. Nauczyciele (często słusznie) domagają się konkretnych rozwiązań w zakresie wdrażania koncepcji teoretycznych w praktyce nauczycielskiej. Także Jan Průcha, nestor czeskiej pedagogiki, zaapelował ostatnio o potrzebę łączenia teorii z praktyką ${ }^{34}$.

Ostatnio z grupą dydaktyków zaprezentowaliśmy zarówno $\mathrm{w}$ pracach teoretycznych ${ }^{35}$, jak i aplikacyjnych ${ }^{36}$ kompleksowe rozwiązanie, które ma uczyć nauczycieli myślenia dydaktycznego, zarówno w doborze treści, jak i sposobach ich transformacji dydaktycznej. Ta nowa koncepcja, którą nazwaliśmy: komunikacyjna nauka o języku czeskim (komunikační nauka o českém jazyku), kontynuuje dobrą tradycję dydaktyki przedmiotowej języka czeskiego, dalej ją

${ }^{32}$ O problemie dezintegracji ogólnie por. J. Slavík et al.: Transdisciplinární didaktika...; o problemie dezintegracji w nauczaniu języka czeskiego por. S. Štěpáník: Výuka češtiny mezi tradicí a inovací...

${ }^{33}$ S. Štěpáník: Nauczyciel języka ojczystego w konflikcie między tradycja a wspótczesnościa. W: Kompetencje nauczyciela polonisty we wspótczesnej szkole. Między schematyzmem a kreatywnościa. Red. K. Maciejak, M. Trysińska. Wydawnictwa Uniwersytetu Warszawskiego, Warszawa 2019, s. 85-101.

${ }_{34}$ J. Průcha: Pedagogický výzkum a využití v praxi — téma pro diskusi. „Pedagogika” 2020, č. 1, s. 97-101. https://doi.org/10.14712/23362189.2019.1584.

${ }^{35}$ S. Štěpáník: Výuka češtiny mezi tradicí a inovací...; Idem: Konstruktivistické a kognitivně-komunikačni paradigma jako východisko koncepce výuky českého jazyka....

${ }^{36}$ S. Štěpáník et al.: Školni výpravy do krajiny češtiny: didaktika českého jazyka pro základni školy. Fraus, Plzeň 2020. 
rozwija, koreluje koncepcje teoretyczne w zakresie pedagogiki przedmiotowej i ogólnej oraz dąży do ich specyficznej realizacji. Koncepcja powstała w wyniku bardzo inspirującej czesko-słowacko-polskiej współpracy.

Chciałbym krótko zaprezentować teoretyczne postulaty komunikacyjnej nauki o języku czeskim:

1. Głównym celem nauczania jest rozwój świadomości językowej ucznia — od spontanicznej świadomości językowej przez świadomość wyuczoną do intencjonalnej świadomości językowej ${ }^{37}$.

2. Wszystkie działania dydaktyczne powinny być kierowane na ucznia i jego potrzeby (komunikacyjne).

3. Podstawowym punktem wyjścia w pracy dydaktycznej jest przedpojęcie ucznia, czyli jego domniemana znajomość zjawisk językowych i funkcjonowania języka, zarówno na poziomie kompetencji, jak i na poziomie performancji.

4. U podstaw koncepcji leży dążenie do integralności w nauczaniu: rzeczywistość językowa i komunikacyjna są z sobą powiązane, poszukuje się równowagi perspektyw ontodydaktycznej i psychodydaktycznej.

5. Nauczanie opiera się na rzeczywistych i aktualnych kontekstach kulturowospołecznych i komunikacyjnych, w nauczaniu stosuje się żywy język.

6. Nauczanie powinno prowadzić uczniów bardziej do opisu i funkcjonalizacji niż do przepisu/definicji; kwestionowana jest koncepcja poprawności językowej, która nadal funkcjonuje w szkole, choć została odrzucona zarówno w dydaktyce, jak i w językoznawstwie.

7. Język postrzegany jest jako zjawisko społeczne - komunikacja służy wyrażeniu określonych intencji komunikacyjnych, występuje w określonych sytuacjach komunikacyjnych, funkcjonuje jako środek interakcji (a nie jako abstrakcja przeznaczona do analizy).

\section{Rezultaty w nauczaniu języka czeskiego}

Niestety na całym świecie język ojczysty znajduje się w centrum wszystkich ustandaryzowanych przepisów dotyczących egzaminów, a Republika Czeska nie stanowi w tym zakresie wyjątku. W chwili obecnej w edukacji powszechnej w Republice Czeskiej funkcjonują dwa państwowe egzaminy, a mianowicie egzamin wstępny do szkół ponadgimnazjalnych, do którego uczniowie przystępują w IX klasie szkoły podstawowej, oraz egzamin maturalny, do którego

37 O pojęciu świadomości językowej zob. J. Horecký: Jazykové vedomie. „Jazykovedný časopis" 1991 , č. 2 , s. $81-88$. 
uczniowie przystępują w IV klasie szkoły średniej. Wymagania dotyczące tych egzaminów są określone w dwóch dokumentach zatytułowanych: Specifikace požadavkü pro jednotnou přijímací zkoušku v přijímacím řizeni na střední školy $v$ oborech vzdělání s maturitni zkouškou: český jazyk a literatura [Specyfikacja wymagań dotyczacych jednolitego egzaminu wstęnego w procedurze przyjmowania do szkót średnich na kierunkach z egzaminem maturalnym: język czeski i literatura] oraz Katalog požadavků pro zkoušky společné části maturitni zkoušky: český jazyk a literatura [Katalog wymagań dotyczących egzaminów z części wspólnej egzaminu maturalnego: język czeski i literatura].

$\mathrm{W}$ dokumentach tych określono głównie to, co jest łatwe do sprawdzenia skupiono się więc przede wszystkim na określeniu zweryfikowanej wiedzy faktograficznej (można ją utożsamić z „małą lingwistyką"). Definiowanie sprawdzonych umiejętności komunikacyjnych odpowiada statycznej koncepcji tekstu. Szczególnie w katalogu egzaminów wstępnych do szkół średnich wymagania można ocenić jako wysoce sformalizowane.

Oba wspomniane rodzaje egzaminów są testami decydującymi, to znaczy mającymi znaczące konsekwencje dla egzaminowanego. Jeszcze większy jest jednak ich efekt zwrotny (washback effect), to jest wpływ na nauczanie, na poziomie celów, treści i metod ${ }^{38}$. W konsekwencji efekt zwrotny w znacznej mierze przysłania zaprojektowaną podstawę jej „krzywym odbiciem” w testach egzaminacyjnych - innymi słowy, nauczyciele postępują zgodnie z zapisami w katalogach i wcześniejszych testach, zamiast kierować się wytycznymi z $R a$ mowego programu edukacyjnego.

\section{Dyskusja}

W nauczaniu języka czeskiego obserwujemy brak powiązań pomiędzy założeniami, procesem a rezultatami.

${ }^{38} \mathrm{O}$ washback effect por. na przykład: J.Ch. Alderson, D. Wall: Does washback exist? "Applied Linguistics" 1993, vol. 2, s. 115-129; L. Cheng, Y. Sun, J. Ma: Review of washback research literature within Kane's argument-based validation framework. „Language Teaching” 2015, vol. 48 (4), s. 436 - 470. https://doi.org/10.1017/S0261444815000233; w nauczaniu języka czeskiego: S. Štěpáník: Vliv nové podoby maturitni zkoušky z českého jazyka a literatury na vyučováni ve výpovědich učiteli̊. „Pedagogická orientace” 2018, č. 3, s. 435-471. https://doi. org/10.5817/PedOr2018-3-435; w nauczaniu języka polskiego: J. Nocoń: Profile szkolnej wiedzy o języku w kontekście egzaminów zewnętrznych. „Annales Universitatis Paedagogicae Cracoviensis: Studia ad Didacticam Litterarum Polonarum et Linguae Polonae Pertinentia" 2017, T. 8, s. $105-117$. 
Na poziomie założeń otwarto innowacyjne „drzwi”. W nowej państwowej strategii edukacyjnej relatywnie dobrze opisano możliwości obecnie funkcjonującej czeskiej szkoły, wyraźnie też wskazano w niej sfery, w których zmiany są konieczne. Również w podstawie programowej sformułowano oczekiwane rezultaty reformy, mniej więcej zgodne z tezami współczesnej dydaktyki języka czeskiego. Należy też mieć nadzieję, że po rewizji Ramowego programu edukacyjnego najnowsze osiągnięcia nauk pedagogicznych i nauki o języku zostaną w tym dokumencie jeszcze bardziej zaakcentowane.

Jeśli chodzi o proces nauczania, to należy powiedzieć, że jesteśmy świadkami znacznej inercji praktyki. Przyczyn takiego stanu jest wiele: niski poziom wiedzy merytorycznej i dydaktycznej nauczycieli (content knowledge i pedagogical content knowledge), bardzo silna tradycja nauczania, podtrzymywana również w przekonaniach nauczycieli (teachers' beliefs), niewłaściwe (lub bezwzględnie złe) podręczniki i inne materiały dydaktyczne, a także niekorzystne warunki systemu szkolnego lub określonych szkół ${ }^{39}$. Za jedną z głównych przyczyn trudności można jednak uznać fakt, że dotychczas niewiele uwagi poświęcono badaniu integralności nauczania oraz krytycznym punktom praktyki nauczania języka czeskiego, co spowodowało, że analiza problemów nauczania nie została mocno osadzona w samym procesie. Ponadto do tej pory nauczycielom brakowało instrumentalizacji teorii w postaci kompleksowej koncepcji tworzenia funkcjonalnego środowiska nauczania i uczenia się. To podstawowy problem wdrażania teorii w działania praktyczne. Dlatego głównym zadaniem dydaktyki języka czeskiego jest dostarczenie nauczycielom aplikacyjnych narzędzi do innowacyjnego myślenia o nauczaniu. Komunikacyjna nauka o języku czeskim odpowiada bezpośrednio na tę potrzebę.

Wymagania wystandaryzowanych egzaminów kolidują ze wspomnianymi zasadami zapisanymi $\mathrm{w}$ strategii edukacyjnej państwa i z zasadami dydaktyki przedmiotowej języka czeskiego — przełożenie podstawy programowej (RPE) na egzaminy w niewielkim stopniu uwzględnia punkt wyjścia współczesnej dydaktyki przedmiotu, a pod pewnymi względami w ogóle jej nie respektuje. To paradoks, że pomiędzy realizacją założeń (zagwarantowaną przez system oświatowy kraju) a rezultatami (w postaci egzaminów) nie ma zgodności. Nawet jednak w tym zakresie zachodzą zmiany, na przykład nowelizacja ustawy o oświacie nr 284/2020 Sb. wprowadza modyfikacje w modelu egzaminu maturalnego.

${ }^{39}$ Szerzej S. Štěpáník: Nauczyciel języka ojczystego w konflikcie między tradycja a wspótczesnościa... 


\section{Zakończenie}

Zgodność pomiędzy teoretycznymi przesłankami nauczania, procesem ich realizacji w tym nauczaniu a jego rezultatami ma absolutnie kluczowe znaczenie dla kształtowania środowiska nauczania i uczenia się oraz dla jego jakości. Pozostańmy przy metaforze szkoły na rondzie z pierwszych stron opracowania: możemy stwierdzić, że „samochód” oznaczający nauczanie języka czeskiego woli jeździć w koło, niż wybrać jeden ze „zjazdów”. Oczywiście niektóre zjazdy są bezpieczniejsze, inne - mniej bezpieczne. Na opisany stan czeskiej praktyki edukacyjnej języka ojczystego wpływa brak połączeń między elementami układu: założenia nauczania — proces wdrażania tych założeń — rezultaty nauczania języka czeskiego, a pojedyncze wymagania w nauczaniu przyczyniają się do całkowitej niespójności systemu.

Ramy systemu edukacyjnego państwa na poziomie teoretycznych założeń można uznać za ścieżkę niepewną, ale bezpieczną, jeśli innowacje, których oczekuje państwowa polityka edukacyjna, są profesjonalnie zagwarantowane. Rola przedmiotowej dydaktyki języka czeskiego staje się więc absolutnie kluczowa w tworzeniu innowacyjnych uwarunkowań nauczania i uczenia się. Zadanie dydaktyków języka czeskiego polega na przygotowaniu dla nauczycieli wsparcia mającego wysoką jakość, a zarazem ukierunkowanego praktycznie, by stanowiło ono pomoc w dostosowaniu procesu nauczania do wymagań aktualnej wiedzy naukowej. Jeśli chcemy osiągnąć taki cel, powinniśmy dużo intensywniej niż dotychczas kierować uwagę teorii dydaktycznej na badanie praktyki oraz szukać możliwości wdrażania koncepcji teoretycznych do praktyki pedagogicznej.

Jednym $\mathrm{z}$ aktów wsparcia w procesie reformowania czeskiej dydaktyki jest komunikacyjna nauka o języku czeskim, która powstała jako most między teorią a praktyką. Podstawową misją tej koncepcji jest wskazanie konkretnego sposobu przełożenia na praktykę teoretycznych zasad kognitywno-komunikacyjnej i konstruktywistycznej dydaktyki języka ojczystego. Komunikacyjna nauka o języku czeskim zmienia perspektywę dydaktyczną: przechodzi od komunikacji do języka i z powrotem — od języka do komunikacji (podczas gdy w realizowanej obecnie koncepcji przechodzi się od języka do komunikacji - o ile w ogóle następuje realne przejście od języka do komunikacji). Istotne jest bowiem, aby poznawanie języka ojczystego następowało dzięki aktywności ucznia w komunikacji, z komunikacją i dla komunikacji (odwołuję się tutaj do stwierdzeń Jadwigi Kowalikowej wobec tekstu: „praca z tekstem, na tekście i dla tekstu" ${ }^{\prime 40}$ ).

${ }^{40}$ Cyt. za: J. Nocoń: Lingwodydaktyka na progu XXI wieku..., s. 133. 
Jeśli eksperci nie wprowadzą konkretnych rozwiązań aplikacyjnych mogących służyć innowacyjnemu nauczaniu języka czeskiego, dobre cele edukacyjnej polityki państwa nie zostaną osiągnięte, ponadto istnieje niebezpieczeństwo, że postępowi rodzice i nauczyciele skierują się ku czwartej drodze. Drogę tę Janík nazywa EDUout ${ }^{41}$ i charakteryzuje jako descholaryzację, pełną popularnych, odpowiednio populistycznych sloganów: „najlepsza szkoła to życie” (i nie trzeba się uczyć); „,wystarczy być z dziećmi”; ,po co się uczyć, skoro wszystko mogę znaleźć w internecie”; „nie ma znaczenia, czego dzieci uczą się w szkole, zwłaszcza kiedy lubią w niej przebywać" itp. Szkoła stanie się wtedy przedmiotem dochodowego biznesu. W Republice Czeskiej tendencje te są stosunkowo żywe, szczególnie w zakresie wychowania przedszkolnego i edukacji wczesnoszkolnej.

Konieczna jest współpraca wszystkich interesariuszy zaangażowanych w kształtowanie edukacji i rozważenie ustanowienia standaryzowanych testów, które mogłyby innowacyjne działania wspierać, a nie — jak obecnie - całkowicie tłumić.

\section{Bibliografia}

ACARA: The Australian curriculum: English version 8.3. Australian Goverment, Sydney 2016.

Adam R.: Určování morfologických kategorii jmen: sonda do praktik začinajících studentu bohemistiky. „Didaktické studie” 2018, č. 1, s. 13-30.

Adam R.: Určováni morfologických kategorii sloves: sonda do praktik začinajicich studentì bohemistiky. „Didaktické studie” 2019, č. 1, s. 56-80.

Adam R.: V karanténě s Novou školou aneb Říkej věty v množném čísle, slepče! „Český jazyk a literatura" 2019-2020, roč. 70, č. 5, s. 235-240.

Adam R. et al.: Co neuměji studenti bohemistiky. „Český jazyk a literatura” 2010/2011, č. 1, s. 8-14.

Alderson J.Ch., Wall D.: Does washback exist? „Applied Linguistics” 1993, vol. 2, s. 115-129.

Bakuła K.: Kształcenie językowe w szkole podstawowej w świetle współczesnych teorii psycholingwistycznych i lingwistycznych. Projekt nowej metodyki. Wydawnictwo Uniwersytetu Wroclawskiego, Wrocław 1997.

Beyond the grammar wars: A Resource for teachers and students on developing language knowledge in the English/literacy classroom. Ed. T. Locke. Routledge, New York 2010.

Betáková V., Jacko J., Zelinková K.: Teória vyučovania slovenského jazyka. Slovenské pedagogické nakladatel'stvo, Bratislava 1984.

Betáková V., Tarcalová Ž.: Didaktika materinského jazyka. Slovenské pedagogické nakladatel’stvo, Bratislava 1981.

${ }^{41}$ Jest to aluzja do nazwy znanej czeskiej organizacji non-profit EDUin, która w Republice Czeskiej przedstawia się jako jedna z najbardziej aktywnych w dziedzinie edukacji. 
Cheng L., Sun Y., Ma J.: Review of washback research literature within Kane's argument-based validation framework. „Language Teaching” 2015, vol. 48 (4), s. 436-470. https://doi. org/10.1017/S0261444815000233.

Chvál M., Šmejkalová M.: Řešení úloh z české syntaxe žáky 4.-9. ročníků základních škol. „Studia paedagogica" 2018, roč. 23, č. 1, s. 106-134. https://doi.org/10.5817/SP2018-1-6.

Čechová M.: Komunikační a slohová výchova. ISV, Praha 1998.

Čechová M.: O potrebě integrace komunikačni a systémové jazykové výuky. „Český jazyk a literatura" 1993/1994, č. 7-8, s. 158-162.

Čechová M.: Srovnáni nesrovnatelného: Znalosti funkčni morfologie u žáků pred 50 lety a dnešnich bohemistů. „Český jazyk a literatura” 2018, roč. 69, č. 1, s. 24-33.

Čechová M.: Teorie a praxe vyučování českému jazyku na gymnáziu. Státní pedagogické nakladatelství, Praha 1982.

Čechová M.: Vyučování slohu. (Úvod do teorie). Státní pedagogické nakladatelství, Praha 1985.

Čechová M.: Zrušíme nejen větné rozbory? „Český jazyk a literatura” 2011/2012, roč. 62, č. 5, s. $237-241$.

Čechová M., Styblík V.: Čeština a jeji vyučování. Didaktika českého jazyka pro učitele základních a střednich škol a studenty učitelství. 2., upravené vyd., v SPN vyd. 1. SPN, Praha 1998.

Dyduchowa A.: Metody kształcenia sprawności językowej uczniów: projekt systemu, model podręcznika. Wydawnictwo Naukowe WSP, Kraków 1988.

Grammar at school: Research on metalinguistic activity in language education. Eds. T. Ribas, X. Fontich, O. Guasch. Peter Lang AG, Brussels 2014.

Hájková E.: Komunikační činnosti a jejich cíle. Pedagogická fakulta Univerzity Karlovy, Praha 2008.

Hájková E.: Učivo o větě na 1. stupni ZŠ. „Didaktické studie” 2013, č. 2, s. 11-19.

Hájková E.: Vztah komunikační a jazykové výchovy na přikladu využití učiva mluvnice. W: S. Štěpáník et al.: Vztah jazyka a komunikace v česko-slovensko-polské didaktické reflexi. Karolinum, Praha 2019, s. 173-190.

Hausenblas K.: Větný rozbor, nebo nalepováni vinětek? „Český jazyk a literatura” 1965/1966, č. 3, s. $207-213$.

Hoffmannová J. et al.: Stylistika mluvené a psané češtiny. Academia, Praha 2016.

Horecký J.: Jazykové vedomie. „Jazykovedný časopis” 1991, č. 2, s. 81—88.

Hrbáček J.: K rozboru syntaktických vztahi̊ ve škole. „Český jazyk a literatura” 1998/1999, č. 1—2, s. $14-25$.

Hrbáček J.: Text a jeho rozbor ve škole. „Český jazyk a literatura” 1999/2000, č. 5-6, s. 109-116.

Janík T.: Od reformy kurikula k produktivní kultuře vyučování a učení. „Pedagogická orientace” 2013, č. 5, s. $634-663$.

Janík T.: Škola na kruhovém objezdu aneb když se to vezme kolem a kolem. „Pedagogická orientace” 2015, č. 5, s. 727-732.

Janík T.: Škola na kruhovém objezdu aneb Když se to vezme kolem a kolem. W: Vzdělání a dnešek. Red. M. Strouhal, S. Štech. Karolinum, Praha 2016, s. 163-178.

Janík T., Lokajíčková V., Janko T.: Komponenty a charakteristiky zakládajici kvalitu výuky: přehled výzkumných zjištění. „Orbis scholae” 2012, č. 3, s. 27-55. https://doi org/10.14712/23363177.2015.31.

Jelínek J.: Nástin dějin vyučováni českému jazyku v letech 1774-1918. Státni pedagogické nakladatelství, Praha 1972.

Jelínek J., Těšitelová M., Styblík V.: Vyučováni českému jazyku v osmém postupném ročníku. Státni pedagogické nakladatelství, Praha 1957.

Język ojczysty w edukacji szkolnej w Polsce, Czechach i na Stowacji. Red. S. Štěpáník, E. Awramiuk. Wydawnictwo Uniwersytetu, Białystok 2020. 
Knowing about language: Linguistics and the secondary English classroom. Eds. M. Giovanelli, D. Clayton. Routledge, London 2016.

Kotenová M.: Je komunikačně orientovaná výuka skladby nedostižnou metou? „Český jazyk a literatura" 2018/2019, č. 2, s. 59-66.

Kowalikowa J., Synowiec H.: Miejsce nauki o języku w ksztatceniu językowym uczniów. W: Ksztatcenie sprawności językowej $i$ komunikacyjnej. Obraz badań $i$ działań dydaktycznych. Red. Z. Uryga, M. Sienko. Wydawnictwo Naukowe Akademii Pedagogicznej, Kraków 2005, s. $48-56$.

Language in the schools: Integrating linguistic knowledge into K-12 teaching. Eds. K. Denham, A. Lobeck. Routledge, New York 2009.

Liptáková L. et al.: Integrovaná didaktika slovenského jazyka a literatúry pre primárne vzdelávanie. Prešovská univerzita v Prešove, Pedagogická fakulta, Katedra komunikačnej a literárnej výchovy, Prešov 2011.

Nagajowa M.: Nauka o języku dla nauki języka. Poradnik metodyczny dla nauczycieli języka polskiego. Wydawnictwo Pedagogiczne ZNP, Kielce 1994.

Nocoń J.: Lingwodydaktyka na progu XXI wieku. Konteksty - koncepcje — dylematy. Wydawnictwo Uniwersytetu Opolskiego, Opole 2018.

Nocoń J.: Profile szkolnej wiedzy o języku w kontekśsie egzaminów zewnętrznych. „Annales Universitatis Paedagogicae Cracoviensis: Studia ad Didacticam Litterarum Polonarum et Linguae Polonae Pertinentia" 2017, T. 8, s. 105-117.

Palenčárová J., Kesselová J., Kupcová J.: Učíme slovenčinu komunikačne a zážitkovo. Slovenské pedagogické nakladatel'stvo - Mladé letá, Bratislava 2003.

Pavelková I.: Postoje žáků k českému jazyku a jejich percepce učiteli. „Didaktické studie” 2013, č. 1, s. $27-45$.

Pavelková I., Škaloudová A., Hrabal V.: Analýza vyučovacích předmětů na základě výpovědi žáků. „Pedagogika” 2010, č. 1, s. 38-61.

Průcha J.: Pedagogický výzkum a využití v praxi — téma pro diskusi. „Pedagogika” 2020, č. 1, s. 97-101. https://doi.org/10.14712/23362189.2019.1584.

Rethinking L1 education in a global era. Understanding the (post-)national L1 subjects in new and difficult times. Eds. B. Green, P.O. Erixon. Springer, New York 2020.

Rysová K.: Několik postřehů z výuky českého jazyka a literatury na SŠ. „Český jazyk a literatura” 2005/2006, č. 5, s. 232-234.

Slavík J. et al.: Transdisciplinárni didaktika: o učitelském sdílení znalostí a zvyšování kvality výuky napřič obory. Masarykova univerzita, Pedagogická fakulta, Brno 2017. https://doi.org/10.5817/ CZ.MUNI.M210-8569-2017.

Style wspótczesnej polszczyzny. Przewodnik po stylistyce polskiej. Red. E. Malinowska, J. Nocoń, U. Żydek-Bednarczuk. Towarzystwo Autorów i Wydawców Prac Naukowych Universitas, Kraków 2013.

Svobodová J.: Jazyková specifika školské komunikace a výuka mateřštiny. Ostravská univerzita. Pedagogická fakulta, Ostrava 2003.

Szymańska M.: Kształcenie językowe w dyskursie edukacyjnym po 1990. W: Świadomość językowa. Red. J. Nocoń, A. Tabisz. [Język a Edukacja. 3]. Wydawnictwo Uniwersytetu Opolskiego, Opole 2014, s. 143-159.

Szymańska M.: Między nauka o języku a rozwijaniem języka. Koncepcje ksztatcenia językowego na przełomie XX i XXI wieku. Wydawnictwo Naukowe UP, Kraków 2016.

Šebesta K.: Od jazyka ke komunikaci. Didaktika českého jazyka a komunikační výchova. Vyd. 2. Karolinum, Praha 2005.

Šmejkalová M.: Čeština a škola — úryvky skrytých dějin. Karolinum, Praha 2010. 
Štěpáník S.: Kognitivně-komunikační princip jako základni východisko výuky českého jazyka. „Český jazyk a literatura" 2018/2019, č. 5, s. 214-223.

Štěpáník S.: Konstruktivistické a kognitivně-komunikačni paradigma jako východisko koncepce výuky českého jazyka. „Pedagogika” 2020, č. 1, s. 5-28. https://doi.org/10.14712/23362189 .2019 .1355 .

Štěpáník S.: Nauczyciel języka ojczystego w konflikcie między tradycja a wspótczesnością. W: Kompetencje nauczyciela polonisty we wspótczesnej szkole. Między schematyzmem a kreatywnościa. Red. K. Maciejak, M. Trysińska. Wydawnictwa Uniwersytetu Warszawskiego, Warszawa 2019, s. $85-101$.

Štěpáník S.: Přiklad výzkumu žákovských představ v české syntaxi. „Pedagogická orientace” 2014, č. 1, s. 111-127. https://doi.org/10.5817/PedOr2014-1-111.

Štěpáník S.: Vliv nové podoby maturitni zkoušky z českého jazyka a literatury na vyučování ve výpovédích učiteli̊. „Pedagogická orientace” 2018, č. 3, s. 435-471. https://doi.org/10.5817/ PedOr2018-3-435.

Štěpáník S.: Výuka češtiny mezi tradicí a inovací. Academia, Praha 2020.

Štěpáník S.: Výuková situace: transformace větného členu na větu a naopak v kontextu větného rozboru. „Komenský” 2016, č. 4, s. 30-39.

Štěpáník S., Chvál M.: Konstruktivismus jako cesta ke zlepšováni výsledků vzděláváni v českém jazyce? „Studia paedagogica” 2016, č. 1, s. 35-56. https://doi.org/10.5817/SP2016-1-3.

Štěpáník S., Liptáková L., Szymańska M.: Cesty ke komunikačně-funkčnímu pojetí v české, slovenské a polské didaktice mateřského jazyka. W: S. Štěpáník et al.: Vztah jazyka a komunikace $v$ česko-slovensko-polské didaktické reflexi. Karolinum, Praha 2019, s. 23-71.

Štěpáník S., Slavík J.: Žákovské prekoncepty jako konstitutivní prvek výuky mateřského jazyka. „Pedagogická orientace" 2017, č. 1, s. 58-80. https://doi.org/10.5817/PedOr2017-1-58.

Štěpáník S. et al.: Školni výpravy do krajiny češtiny: didaktika českého jazyka pro základní školy. Fraus, Plzeň 2020.

Štěpáník S. et al.: Vztah jazyka a komunikace v česko-slovensko-polské didaktické reflexi. Karolinum, Praha 2019.

Teaching of national languages in the V4 countries. Eds. M. Pieniążek, S. Štěpáník. Charles University, Praha 2016.

Zimová L.: Ještě jednou k výuce skladbě. „Český jazyk a literatura” 2015/2016, č. 4, s. 164-169.

Zimová L.: Když se řekne skladba... „Český jazyk a literatura” 2005/2006, č. 5, s. 209-214.

Zimová L.: O potřebnosti větného rozboru. „Český jazyk a literatura” 2011/2012, č. 5, s. 241-244.

Zimová L.: Vyjadřování větných členů infinitivem jako problém didaktický. „Český jazyk a literatura” 1997/1998, č. 9-10, s. 205-211.

Zimová L.: Zpuisoby vyjadřováni podmětu jako problém didaktický. „Český jazyk a literatura” 1998/1999, č. 3 - 4, s. $63-67$. 